\title{
OPTIMALISASI EDUKASI PERPAJAKAN BAGI GENERASI MILENIAL MELALUI VIDEO
}

\author{
Agus Suharsono a, Selly Galvani ${ }^{\mathrm{b}}$ \\ a BDK Yogyakarta, JI Solo Km 11, Sleman, Yogyakarta, Email: gusharpramudito@gmail.com \\ b KPP Pratama Tigaraksa, JI Scientia Boulevard Blok U No.5, Tangerang, \\ Email: selly.galvani@gmail.com
}

\begin{abstract}
The Directorate General of Taxes through various activities routinely conducts tax education on the topic of raising tax awareness for the young generation. This tax education must cover as many millennial generations as possible by utilizing the development of information technology, such as in the form of video. This study aims to find out how tax education by using the video method are suitable for the millennial generation. This study uses qualitative methods and questionnaire sheets instrument to facilitate data collection. The results of this study are: social media is the most appropriate method in promoting video as widely as possible, creative ideas are needed to match with the target audience, and learning videos help to understand the material better.
\end{abstract}

\section{ABSTRAK}

Saat ini Direktorat Jenderal Pajak melalui berbagai kegiatannya secara rutin melakukan penyuluhan dengan topik peningkatan kesadaran perpajakan bagi generasi muda. Edukasi perpajakan ini harus mencakup generasi milenial sebanyak-banyaknya dengan memanfaatkan perkembangan teknologi informasi salah satunya dalam bentuk video. Penelitian ini bertujuan untuk mengetahui bagaimana edukasi perpajakan dengan video yang sesuai dengan generasi milenial. Penelitian ini menggunakan metode kualitatif dan untuk mempermudah pengumpulan data digunakan juga instrument lembar kuesioner. Hasil dari penelitian ini adalah: media sosial merupakan metode yang paling tepat dalam mempromosikan video seluas-luasnya, ide kreatif dibutuhkan untuk menyesuaikan dengan target penonton, dan video pembelajaran membantu dalam memahami materi dengan lebih baik.

Kata Kunci: edukasi perpajakan, video, milenial, media sosial 


\section{PENDAHULUAN}

\subsection{Latar Belakang}

Peranan pajak dalam Anggaran Pendapatan dan Belanja Negara (APBN) sangat signifikan. Berdasarkan Undang-Undang Nomor 12 Tahun 2018 tentang APBN 2019, dari seluruh penerimaan negara sebesar Rp2,165 kuadriliun, porsi penerimaan pajak termasuk bea cukai dan bea masuk adalah sebesar Rp1,786 kuadriliun atau 83\%. Direktorat Jenderal Pajak (DJP) bertanggung jawab atas penerimaan Pajak Penghasilan (PPh), Pajak Pertambahan Nilai (PPN), dan Pajak Bumi dan Bangunan sektor Perkebunan, Perhutanan dan Pertambangan (PBB P3) sebesar Rp1,568 kuadriliun atau 72\% dari APBN atau 88\% dari penerimaan seluruh pajak (RI, Kemenkeu 2018). Dalam rangka mencapai target pendapatan negara tersebut, Pemerintah melakukan langkah-langkah perbaikan di sektor pendapatan negara, antara lain peningkatan tingkat kepatuhan wajib pajak dan membangun kesadaran pajak untuk menciptakan ketaatan membayar pajak atau sustainable compliance (RI 2018). Kepatuhan wajib pajak merupakan kunci tercapainya target penerimaan pajak karena sistem perpajakan Indonesia adalah self assessment, masyarakat wajib pajak diberi kepercayaan untuk membayar dan melaporkan kewajiban perpajakannya. Penjelasan Umum Undang-Undang Ketentuan Umum dan Tata Cara Perpajakan (KUP) tahun 2000 menjelaskan bahwa pembinaan masyarakat wajib pajak dapat dilakukan melalui berbagai upaya, antara lain pemberian penyuluhan pengetahuan perpajakan baik melalui media massa maupun penerangan langsung kepada masyarakat.

DJP melaksanakan penyuluhan dalam rangka meningkatkan kepatuhan wajib pajak, meningkatkan penerimaan pajak, serta meningkatkan kesadaran perpajakan calon wajib pajak dengan topik peningkatan kesadaran perpajakan bagi generasi muda. Salah satu wujud peningkatan kesadaran perpajakan bagi generasi muda adalah Program Inklusi Kesadaran Pajak yang bekerjasama dengan Dirjen Pembelajaran dan Kemahasiswaan Kemenristekdikti dengan memasukkan materi kesadaran pajak dalam kurikulum pendidikan nasional. Selain itu pada Tahun 2017, pegawai DJP turun langsung secara serentak dalam acara Pajak Bertutur kepada 127.459 siswa di 2.182 sekolah mulai SD, SMP, SMA, dan perguruan tinggi se-Indonesia. Kegiatan tersebut tercatat dalam rekor sebagai edukasi sadar pajak dengan peserta terbanyak. Capaian tersebut adalah sebuah prestasi besar, namun masih banyak siswa atau mahasiswa yang juga perlu mendapatkan edukasi perpajakan.

Menkeu meminta generasi muda untuk tidak terburu-buru berpandangan negatif soal kewajiban membayar pajak (Embu, 2018). Generasi muda atau generasi milenial akan mendominasi kehidupan ke depan, maka DJP perlu memikirkan upaya untuk mendekatkan pajak pada generasi milenial ini (Antalina, 2018). Tahun 2030-2040, Indonesia diprediksi akan mengalami masa bonus 
demografi karena 65\% jumlah penduduk adalah usia produktif yang potensial menjadi wajib pajak masa depan (Afandi, 2017). Indonesia dapat belajar dari Jepang yang pernah mengalami bonus demografi pada tahun 1950 dan membuat Jepang menjadi negara dengan kekuatan ekonomi tertinggi ke-3 di dunia (Silitonga, 2018). Berdasarkan penelitian terdahulu tersebut diketahui penting untuk melakukan edukasi perpajakan kepada generasi milenial.

Hasil penelitian Pew Research Center tahun 2010 memperlihatkan bahwa karakteristik generasi millenial adalah: 1) lebih percaya User-Generated Content atau konten yang dibuat oleh perorangan, 2) memilih ponsel dibanding TV, 3) wajib memiliki media sosial sebagai tempat berkomunikasi dan berekspresi, 4) kurang suka membaca secara konvensional, 5) lebih mengerti teknologi dibanding orangtua mereka, 6) cenderung tidak loyal namun bekerja efektif, dan 7) mulai banyak melakukan transaksi secara cashless (Winasti, 2016). Media digital dapat dimanfaatkan untuk memudahkan edukasi pajak generasi milenial (Nuraliyah, 2018). Upaya edukasi perpajakan untuk generasi milenial adalah: 1) menanamkan nilai melalui media yang sesuai dan relevan, 2) membentuk wadah offline maupun online, 3) membuat media edukasi perpajakan yang mudah diakses seiring kemajuan teknologi seperti Twitter, Facebook, ataupun YouTube (Susanto, 2018).

Untuk itu edukasi perpajakan ke depan harus dapat mencakup lebih banyak generasi milenial sebagai sasaran edukasi dengan memanfaatkan perkembangan tehnologi informasi salah satunya berbentuk video.

\subsection{Rumusan Masalah}

Berdasarkan latar belakang masalah dalam penelitian ini adalah seperti apa mekanisme edukasi perpajakan dengan video yang secara efektif dapat tersampaikan pada generasi milenial?

\subsection{Tujuan Penelitian}

Tujuan penelitian ini adalah untuk mengetahui mekanisme edukasi perpajakan dengan video yang sesuai dengan generasi milenial.

\section{KERANGKA TEORITIS \\ 2.1 Edukasi Perpajakan}

Ketentuan melakukan edukasi perpajakan kepada masyarakat tidak dapat ditemukan dalam batang tubuh, namun dapat ditemukan dalam Penjelasan Umum Undang-Undang Nomor 6 Tahun 1983 Tentang Ketentuan Umum dan Tata Cara Perpajakan beserta perubahannya yaitu: Undang-Undang Nomor 6 Tahun 1983 Tentang Ketentuan Umum dan Tata Cara Perpajakan, Undang-Undang Nomor 9 Tahun 1994 Tentang Perubahan Atas Undang-Undang Nomor 6 Tahun 1983 Tentang Ketentuan Umum dan Tata Cara Perpajakan, Undang-Undang Nomor 16 Tahun 2000 Tentang Perubahan Kedua Atas Undang-Undang Nomor 6 Tahun 1983 Tentang Ketentuan Umum dan Tata Cara Perpajakan yang disebutkan bahwa pembinaan 
masyarakat wajib pajak dapat dilakukan melalui berbagai upaya, antara lain pemberian penyuluhan pengetahuan perpajakan baik melalui media massa maupun penerangan langsung kepada masyarakat. Walaupun dalam Penjelasan Umum Undang-Undang Nomor 28 Tahun 2007 Perubahan Ketiga Atas Undang-Undang Nomor 6 Tahun 1983 Tentang Ketentuan Umum dan Tata Cara Perpajakan tidak disebutkan tentang penyuluhan perpajakan, namun tidak berarti DJP tidak mempunyai kewajiban untuk melakukan penyuluhan perpajakan.

Peraturan Menteri Keuangan Nomor 206/PMK.01/2014 tentang Organisasi Dan Tata Kerja Kementerian Keuangan mengatur tugas dan fungsi DJP sebagai berikut. Pertama, Pasal 363 mengatur bahwa DJP mempunyai tugas merumuskan serta melaksanakan kebijakan dan standardisasi teknis di bidang perpajakan. Kedua, Pasal 364 mengatur bahwa dalam melaksanakan tugasnya DJP menyelenggarakan fungsi: perumusan kebijakan di bidang perpajakan, pelaksanaan kebijakan di bidang perpajakan, penyusunan norma, standar, prosedur, dan kriteria di bidang perpajakan, pemberian bimbingan teknis dan evaluasi di bidang perpajakan, dan pelaksanaan administrasi DJP. Ketiga, Pasal 537 mengatur bahwa Direktorat P2HUMAS mempunyai tugas merumuskan serta melaksanakan kebijakan dan standardisasi teknis di bidang penyuluhan, pelayanan, dan hubungan masyarakat. Keempat, Pasal 538 mengatur bahwa dalam melaksanakan
Direktorat P2HUMAS menyelenggarakan fungsi: penyiapan perumusan kebijakan di bidang penyuluhan, pelayanan, dan hubungan masyarakat; penyiapan pelaksanaan kebijakan di bidang penyuluhan, pelayanan, dan hubungan masyarakat; penyiapan penyusunan norma, standar, prosedur dan kriteria di bidang penyuluhan, pelayanan, dan hubungan masyarakat; penyiapan pemberian bimbingan teknis dan evaluasi di bidang penyuluhan, pelayanan, dan hubungan masyarakat; dan pelaksanaan urusan tata usaha direktorat. Kelima, Pasal 540 mengatur bahwa Subdirektorat Penyuluhan Perpajakan mempunyai tugas melaksanakan penyiapan, penelaahan, dan penyusunan kebijakan, serta pemantauan, pengendalian, dan evaluasi pelaksanaan kebijakan teknis penyuluhan, serta pelaksanaan pengelolaan perpustakaan, dokumentasi peraturan perpajakan dan non perpajakan. Keenam, Pasal 541 mengatur bahwa dalam melaksanakan tugasnya Subdirektorat Penyuluhan Perpajakan menyelenggarakan fungsi: penyiapan penelaahan dan penyusunan kebijakan teknis penyuluhan; penyiapan penelaahan dan penyusunan kebijakan teknis pengelolaan perpustakaan, dokumentasi peraturan perpajakan, dan peraturan non perpajakan; pemantauan, pengendalian, dan evaluasi pelaksanaan teknis penyuluhan; pemantauan, pengendalian, dan evaluasi pelaksanaan teknis pengelolaan perpustakaan, dokumentasi peraturan perpajakan, dan peraturan non perpajakan; penyiapan teknik, metode, dan materi penyuluhan pajak; perancangan dan penyiapan 
sarana penyuluhan perpajakan; penyiapan rencana kebutuhan dan bahan pembinaan tenaga penyuluhan; penyiapan jawaban atas pertanyaan masyarakat, riset pelajar dan mahasiswa, konsultasi perpajakan dan tugas pelayanan penyuluhan lainnya di bidang perpajakan; pelaksanaan dokumentasi peraturan perpajakan dan non perpajakan; dan pelaksanaan pengelolaan perpustakaan.

Berdasarkan ketentuan tersebut diketahui bahwa DJP mempunyai tugas untuk melaksanakan edukasi perpajakan berupa penyuluhan perpajakan yang menjadi tugas Direktur P2HUMAS yang didelegasikan kepada Subdirektorat Penyuluhan Perpajakan.

$$
\text { Hasil Survei Pengukuran }
$$

Efektivitas Penyuluhan Perpajakan 2017 memperlihatkan bahwa DJP memperoleh skor indeks efektivitas penyuluhan sebesar 3,28 dalam rentang 0-4. Bentuk edukasi perpajakan tatap muka langsung tahun 2017 sebanyak 35.749. Selain itu juga diadakan kelas pajak sebanyak 14.790 kali. Kelas pajak adalah edukasi perpajakan secara tatap muka dengan lingkup jumlah peserta yang terbatas. Wajib Pajak yang ingin mengikuti Kelas Pajak dapat melakukan pendaftaran secara langsung ke unit kantor melalui telepon atau secara online melalui situs www.pajak.go.id. Selain itu juga dilakukan edukasi perpajakan secara tidak langsung melalui telepon, surel, dan live chat, situs khusus materi perpajakan, e-mail blast, dan situs DJP. Di tingkat Kanwil edukasi perpajakan dilakukan dengan membentuk Tax Center yang bekerja sama dengan perguruan tinggi atau organisasi nirlaba setempat, yang Sampai dengan tahun 2017 sudah terbentuk 185 unit. Tax Center merupakan pusat informasi, pendidikan dan pelatihan perpajakan yang mempunyai peran signifikan dalam meningkatkan kesadaran, kepedulian, dan kepatuhan pajak. Adapun bentuk kegiatannya, yaitu sosialisasi perpajakan, konsultasi perpajakan, dukungan narasumber dari DJP, pelatihan di bidang perpajakan, penelitian dan kajian akademis di bidang perpajakan (DJP, 2018).

Berdasarkan Laporan Tahunan DJP tahun 2017 diketahui agar penyuluhan perpajakan semakin efektif dan tepat sasaran, sebaiknya penyuluhan lebih intensif diberikan kepada wajib pajak yang tingkat kepatuhannya rendah yang umumnya lebih disebabkan karena ketidaktahuan bukan karena tidak mau membayar pajak. Kanal yang memudahkan untuk memperoleh informasi perpajakan adalah situs khusus materi perpajakan, e-Mail blast, situs DJP. Tema yang dibutuhkan wajib pajak adalah mekanisme pengisian SPT, aplikasi elektronik, serta hak dan kewajiban wajib pajak. Tema yang dibutuhkan non-wajib pajak adalah hak dan kewajiban wajib pajak, mekanisme pengisian SPT, peraturan perpajakan, dan mekanisme pendaftaran PKP (DJP, 2018).

Keputusan Dirjen Pajak Nomor KEP-313/PJ/2017 menetapkan tanggal 14 Juli sebagai Hari Pajak. Pada tahun 2018, dengan tema "Meningkatkan Kesadaran Pajak", Hari Pajak diselenggarakan salah satunya dengan lomba menulis artikel pajak untuk mengetahui minat dan pandangan generasi milenial, 
yang diwakili oleh mahasiswa, tentang peran penting pajak untuk kesinambungan pembangunan bangsa. Pengumuman ini direspon dengan antusiasme yang tinggi, terlihat dari 449 artikel yang masuk kemudian disaring menjadi 20 artikel terbaik yang diterbitkan menjadi buku (DJP, 2018). Berdasarkan artikel-artikel tersebut dan penelitian Susanto tahun 2018 sebagaimana disebutkan dalam latar belakang diketahui salah satu media pembelajaran yang sesuai untuk generasi milenial dalam bentuk video. Penelitian ini akan menganalisa edukasi perpajakan kepada non-wajib pajak generasi milenial dalam bentuk video edukasi pembelajaran.

\subsection{Generasi Milenial}

Zemke dkk mengelompokan generasi menjadi empat berdasarkan tahun lahirnya sebagai berikut: 1) The Traditionalists (sebelum tahun 1943) yang tumbuh di tengah Depresi Besar dan PD \| dan menghadapi dunia dengan sikap yang bisa dilakukan; 2) The Baby Boomers (1943-1960) yang tumbuh selama dan setelah PD II dan dibesarkan di era optimisme ekstrim, peluang, dan kemajuan; 3) Generation Xers (1960-1980) yang ditandai dengan kebangkitan Asia; dan 4) Millennials (1980-2004) adalah anak-anak yang disayangi, dipelihara, dan dilindungi (Zemke et.al, 2013). Grail Research menyebut generasi milenial dengan Net Generation, Digital Generations, atau Gen Next yang meliputi: 1) Generasi Y (1980-1995) yang menjadi saksi munculnya teknologi digital yang dapat memfasilitasi komunikasi seperti e-mail dan sms yang nyaman akan teknologi dan loyal kepada sebuah brand; 2) Generasi Z (199,-2010) merupakan generasi yang lebih fasih menggunakan teknologi dan gadget bahkan sangat bergantung pada teknologi digital seperti internet dan situs sosial networking; 3) Generasi Aplha (2010-2023) adalah generasi yang muncul dari krisis ekonomi yang luas dan lebih fasih terhadap teknologi, lebih berpendidikan dari generasi sebelumnya. Karakteristik generasi Z terhadap tehnologi adalah sebagai berikut: 1) nyaman dengan dan bahkan tergantung pada teknologi yang berdasarkan survey global lebih menyukai menonton dengan streaming, melalui video on demand dibandingkan TV tradisional; 2) memiliki akses yang sangat besar terhadap teknologi, berkomunikasi melalui berbagai saluran jejaring sosial; 3) lebih menyukai pendekatan digital dan merasa lebih mudah mempelajari sesuatu melalui internet; dan 4) memiliki konsen atas banyak isu global seperti global warming, terorisme, go green, daur ulang, dan pengurangan konsumsi energi (Kusma, 2013).

Yanuar mengutip Bencsik karakteristik generasi dalam penggunaan IT juga berbeda, Baby Boomer: kurang lengkap; Generasi X: percaya diri; Generasi $Y$ : sudah menjadi bagian dari kehidupan sehari-harinya; dan Generasi Z: Intuitif (Putra, 2016). Sedangkan cara berbagi pengetahuan, Baby Boomer: bersedia secara sukarela; Generasi X: didasarkan pada mutualitas 
dan kerja sama; Generasi Y: mendasarkan pada kepentingan diri atau jika terpaksa; dan Generasi Z: secara virtual, mudah, cepat, bukan untung-untungan, dan tanpa taruhan, terpublikasi (Bencsik, 2016). Untuk menciptakan kesadaran pajak perlu didukung oleh generasi milenial yaitu mereka yang lahir tahun 1980-2000an yang selain aktif dan kreatif juga melek teknologi dan media sosial. Edukasi perpajakan bagi mereka harus dikemas dengan menarik dalam wujud: 1) majak: manfaat pajak, 2) kompak: komparasi pajak dengan negara lain, 3) ketebak: keterbukaan pajak dari sisi penggelolaan, dan 4) sosialisasi e-pajak (Nilasari, 2018). Berdasarkan penelitian terdahulu tersebut diketahui bahwa media edukasi perpajakan yang tepat untuk generasi milenial adalah video yang terpublikasi dan mudah diakses secara online.

\subsection{Video Edukasi Perpajakan}

Edukasi perpajakan selain dilakukan secara tatap muka juga dilakukan memanfaatkan internet atau dikenal dengan istilah pendidikan jarak jauh. Pengembangan pendidikan jarak jauh bertujuan menyediakan akses seluas-luasnya yang tidak berkesempatan ikut tatap muka karena kendala ekonomi, geografis, transportasi, maupun sosial budaya sehingga cocok untuk Indonesia yang mempunyai penduduk sangat besar dan wilayah yang luas. Prinsip pendidikan jarak jauh adalah: 1) terbuka, individual, dan berbasis teknologi pendidikan; 2) diselenggarakan pada berbagai jenjang, jalur, dan jenis pendidikan dengan peserta terpisah, mandiri, terstruktur, dan terbimbing; dan 3) berbasis IT (Warsita 2011). Manfaat edukasi perpajakan menggunakan IT adalah cepat, konsisten, tepat, dapat dipercaya, dapat dilakukan penggulangan dengan sama, meningkatkan produktivitas, dan mencetuskan kreativitas. Langkahlangkah edukasi perpajakan berbasis IT menurut Bramble adalah: 1) menentukan sasaran pembelajaran, 2) membuat isi pembelajaran, 3) menilai terhadap metode yang ada, dan 4) merancang proses pembelajaran (Munir, 2012). Berdasarkan penelitian terdahulu tersebut diketahui bahwa edukasi perpajakan agar lebih efektif dan efisien dapat dilakukan melalui video, karena video memiliki aspek audio sekaligus visual sehingga dapat menjangkau ketertarikan lebih banyak audiens, baik yang hanya menyukai audio saja atau visual saja.

Pembuatan video pembelajaran yang melibatkan mahasiswa direspon positif oleh mahasiswa (Nurfathiyah, 2011). Pembelajaran menggunakan video dengan partisipasi peserta pembelajaran dengan model pembelajaran inkuiri lebih efektif dibanding model konvensional (Arjaya, 2016). Mahasiswa yang diberi tugas menganalisis video sebagian besar memberi respon positif. Untuk menganalisis video tahap perkembangan kognitif, sosial, dan moral agar lebih menekankan pada analisis kebenaran konsep (Susantini, 2013). Ada pengaruh penggunaan media video pembelajaran terhadap pemahaman tentang komunikasi dan konseling obat pada mahasiswa farmasi. Penggunaan media 
video pembelajaran dapat menjadi salah satu alternatif dalam meningkatkan pemahaman tentang mahasiswa tentang komunikasi, informasi, dan edukasi (Mardiati, 2018). Video pembelajaran dapat menjadi salah satu solusi pemecahan masalah dalam pemahaman teknik memvisualisasikan naskah. Video ini diunggah ke media sosial youtube untuk memudahkan mahasiswa dalam mengakses video ini kapan saja dan dimana saja selama terdapat jaringan internet (Yuwono, 2015). Media pembelajaran video sangat berperan penting dalam meningkatkan hasil belajar mahasiswa, diharapkan dosen untuk menggunakan video, sehingga hasil belajar mahasiswa menjadi lebih baik (Thamrin, 2015).

\section{METODE PENELITIAN}

Penelitian ini merupakan penelitian terapan dengan tujuan untuk digunakan dengan segera memperbaiki praktik-praktik yang ada (Nasir, 1988). Metode penelitian yang digunakan adalah penelitian tindakan yang biasanya dilakukan oleh guru, pendidik, penyelenggara pendidikan, konseling, penasehat pendidikan, dan pihak lainnya yang menaruh minat dalam lingkungan belajar-mengajar untuk meningkatkan proses belajar-mengajar (Mertler, 2011). Ciri khusus penelitian tindakan adalah: fokus praktis, praktik pendidik-peneliti itu sendiri, kolaborasi, prosesnya dinamis, rencana tindakan, dan melaporkan penelitiannya (Cresswelll, 2015). Penelitian tindakan bukan sebuah upaya untuk problem solving atas sesuatu yang kita anggap salah, namun, lebih sebagai upaya untuk memahami tentang bagaimana untuk mengubah atau how to improve (Gani, 2014).

Penelitian ini bersifat bersifat kualitatif dengan sumber data utamanya adalah kata-kata dan tindakan, selebihnya adalah data tambahan seperti dokumen (Moleong, 2015). Sedangkan yang menjadi instrumen penelitian adalah peneliti itu sendiri (Sugiyono, 2015). Namun untuk mendapatkan data sebanyak mungkin dan guna mempermudah dalam mengumpulkan data juga digunakan instrumen lain berupa lembar evaluasi, lembar kuesioner, catatan observasi, wawancara, dokumentasi, dan poliangulasi. Analisis data menggunakan logika untuk memahami pola dan kecenderungan dalam data melalui tiga tahap yaitu pengkodean, mendeskripsikan karakteristik utama, dan menginterpretasikan data atau logiko-induktif (Mertler, 2011). Prosedur penelitian ini menggunakan model menurut Craig A. Mertler melalui empat tahap yang terdiri dari sembilan langkah pelaksanaan (Mertler, 2011) sebagaimana dalam Tabel 1. 
Tabel 1 Tahapan dan Langkah Penelitian

\begin{tabular}{ll}
\hline \multicolumn{1}{c}{ Tahapan } & \multicolumn{1}{c}{ Langkah Pelaksanaan } \\
\hline 1. Perencanaan & $\begin{array}{l}\text { 1. Identifikasi dan pembatasan tema } \\
\text { 2. Pengumpulan informasi } \\
\text { 3. Tinjauan pustaka } \\
\text { 4. Penyusunan rencana penelitian }\end{array}$ \\
\hline 2. Pengambilan Tindakan & 5. Pengumpulan data \\
& 6. Analisis data \\
\hline 3. Pengembangan & 7. Penyusunan rencana aksi \\
\hline 4. Refleksi & 8. Berbagi dan penyampaian hasil penelitian
\end{tabular}

\section{HASIL DAN PEMBAHASAN}

Analisis dan pembahasan hasil penelitian mengikuti tahapan penelitian tindakan menurut Metler dengan penyesuaian sebagaimana Tabel 2.

Tabel 1 Tahapan dan Langkah Penelitian

\begin{tabular}{|c|c|c|}
\hline Penelitian ini & Tahapan & Langkah Pelaksanaan \\
\hline $\begin{array}{l}\text { - Bab Pendahuluan } \\
\text { - Bab Tinjauan } \\
\text { Pustaka } \\
\text { - Bab Metode } \\
\text { Penelitian }\end{array}$ & - Perencanaan & $\begin{array}{ll} & \text { Identifikasi dan pembatasan } \\
\text { tema } \\
\circ \text { Pengumpulan informasi } \\
\circ \text { Tinjauan pustaka } \\
\circ \text { Penyusunan rencana } \\
\text { penelitian } \\
\end{array}$ \\
\hline - Analisis & $\begin{array}{l}\text { - Pengambilan } \\
\text { Tindakan }\end{array}$ & $\begin{array}{l}\text { - Pengumpulan data } \\
\text { - Analisis data }\end{array}$ \\
\hline - Pembahasan & $\begin{array}{l}\text { - Pengembangan } \\
\text { - Refleksi }\end{array}$ & $\begin{array}{ll} & \text { Penyusunan rencana aksi } \\
\circ & \text { Berbagi dan penyampaian } \\
\text { hasil penelitian } \\
\circ \text { Peninjauan proses penelitian }\end{array}$ \\
\hline
\end{tabular}

Tahapan perencanaan berupa identifikasi dan pembatasan tema, pengumpulan informasi, tinjauan pustaka, dan penyusunan rencana penelitian sudah dilakukan dan dituangkan dalam pendahuluan, kerangka teoritis dan metode penelitian. Analisis berupa pengambilan tindakan yang meliputi pengumpulan data dan analisis data. Sedangkan pembahasan adalah tahapan pengembangan berupa penyusunan rencana aksi dan refleksi yang meliputi berbagi dan penyampaian hasil penelitian serta peninjauan proses penelitian. 


\subsection{Analisis}

Penelitian ini dilakukan kepada mahasiswa D3 Pajak PKN STAN semester 3 Tahun Ajaran 2018/2019 untuk Mata Kuliah Keuangan Publik. Mahasiswa diminta membuat video untuk setiap bab yang diajarkan sesuai dengan Rencana Pembelajaran Semester (RPS) yang telah ditetapkan. Pembuatan video dimulai pada Bulan Oktober - November 2018 dan total ada enam video yang dibuat.

Mahasiswa dibagi dalam enam kelompok dan tiap kelompok membuat satu video pembelajaran. Tidak ada ketentuan khusus dalam pembuatan video. Hal ini dilakukan agar mahasiswa bebas menentukan tema dan konten dari videonya masing-masing. Setelah semua video terkumpul, selanjutnya diunggah di youtube dalam satu akun khusus yang telah dibuat agar lebih sistematis dan memudahkan dalam pencarian. Selanjutnya mahasiswa diharuskan mempromosikan video yang telah mereka buat dengan seluas-luasnya. Agar video dapat disebarluaskan sebanyak-banyaknya mahasiswa diberikan reward nilai tergantung dari jumlah viewers. Semakin banyak orang yang menonton video mereka, semakin tinggi nilai yang akan didapat. Selain disebarluaskan kepada mahasiswa, promosi juga dilakukan oleh dosen pengajar Mata Kuliah Keuangan Publik untuk disebarluaskan di kelas masing-masing.

Periode promosi dilakukan selama Bulan Desember 2018 sejak semua video diunggah ke youtube. Setelah periode promosi selesai dan jumlah penonton untuk masing-masing video sudah diketahui, selanjutnya dibagikan kuesioner untuk mahasiswa pembuat video dan mahasiswa pemakai video.

$$
\text { Kuesioner untuk mahasiswa }
$$

pembuat video bertujuan untuk mengetahui pendapat mereka tentang pembuatan video pembelajaran dan teknik promosi yang digunakan untuk menyebarluaskan video tersebut. Untuk mahasiswa pemakai video, kuesioner dibuat untuk mengetahui pendapat mereka mengenai video pembelajaran, apakah video tersebut membantu mereka dalam memahami materi. Dari hasil kuesioner tersebut berikut beberapa pendapat dan saran yang diberikan:

a. Mahasiswa pembuat video

Berikut pendapat dari mahasiswa pembuat video terkait dengan tugas pembuatan video pembelajaran Mata Kuliah Keuangan Publik:

1. Menarik

Pembuatan video pembelajaran ini menumbuhkan sisi kreatif dari mahasiswa. Ide yang bermunculan beragam dan orisinil, sehingga menghasilkan video yang menarik untuk ditonton. Selain itu, pemutaran video pembelajaran disela-sela proses belajar juga ampuh untuk menghilangkan kejenuhan dalam belajar di kelas.

2. Fleksibel

Video pembelajaran ini dapat diakses oleh siapapun, dimanapun dan kapanpun, selama terhubung dengan jaringan internet. Hal ini sangat memudahkan mahasiswa jika ingin belajar dan 
mengulang-ulang materi karena tidak harus bertatap muka di kelas.

3. Ilmu dapat tersebar luas

Seiring dengan perkembangan teknologi, internet menjadi hal yang tidak terpisahkan dari kehidupan sehari-hari. Video pembelajaran ini tidak hanya dapat dinikmati oleh mahasiswa kelas, tetapi juga seluruh orang yang mengakses melalui youtube.

Selain pendapat diatas, ada juga saran dan masukan yang disampaikan oleh mahasiswa pembuat video, antara lain:

1. Komposisi materi

Tidak adanya keseragaman untuk tiap kelompok menyebabkan bobot materi berbeda - beda. Ada kelompok yang menjelaskan dan menjabarkan materi secara lengkap dan komprehensif beserta contoh-contohnya, namun ada juga kelompok yang menjelaskan materi secara tidak lengkap. Sebaiknya, dari awal dibuat pedoman yang dipakati antara dosen dan mahasiswa untuk menentukan cakupan materi yang harus dijelaskan agar video pembelajaran dapat menjelaskan seluruh materi beserta aplikasinya di dunia nyata.

\section{Kualitas Video}

Untuk membuat video yang baik dibutuhkan sarana, prasarana, dan kemampuan editing video yang baik. Hal ini menjadi keterbatasan bagi mahasiswa karena tidak semua orang memiliki hal tersebut. Akibatnya, beberapa video kualitasnya menjadi kurang baik.
Hal ini sangat disayangkan apalagi ketika konsep dan materi video sudah dipersiapkan dengan baik. Kedepannya sebaiknya mempertimbangkan komposisi mahasiswa dalam kelompok agar mahasiswa yang memiliki sarana, prasarana, dan kemampuan editing video tersebar di semua kelompok.

b. Mahasiswa pemakai video

Selain untuk mahasiswa pembuat video, kuesioner juga disebar untuk mahasiswa pemakai video. Mahasiswa ini mencakup seluruh mahasiswa, selain mahasiswa pembuat video, yang menonton video pembelajaran baik mahasiswa dari PKN STAN maupun mahasiswa dari universitas lain. Berikut beberapa pendapat dari mahasiswa pemakai video:

1. Membantu proses pembelajaran

Setelah melihat video ini, beberapa mahasiswa merasakan manfaat karena mendukung proses belajar di kelas. Bahasa yang ringan dan mudah dipahami menjadi nilai tambah tersendiri karena hal tersebut membantu mahasiswa dalam mendalami materi dengan lebih baik.

2. Kreatif

Bermacam video yang tersedia dengan konsep yang beragam menjadi hal yang menarik ditengah metode belajar yang selama ini dialami oleh mahasiswa. Ide-ide kreatif yang disajikan dalam bentuk video menjadi tontonan yang tidak hanya menghibur, tetapi juga memberikan nilai tambah utamanya terkait dengan Keuangan Publik. 
Selain beberapa pendapat dari mahasiswa pemakai video diatas, terdapat juga saran dan masukan yang dapat dijadikan dasar perbaikan kedepannya, antara lain:

1. Durasi terlalu lama Beberapa video dinilai memiliki durasi yang terlalu panjang. Akibatnya di titik tertentu, penonton akan merasa bosan terlebih apabila alur cerita datar. Sebaiknya durasi video ditentukan dan disepakati bersama sejak awal.

2. Cakupan materi

Walaupun sudah ada RPS sebagai pedoman pembelajaran mahasiswa selama satu semester, namun pada video pembelajaran yang dibuat oleh mahasiswa masih ada materi yang tidak tercakup didalamnya. Sebaiknya sebelum video dipublikasikan, dosen melakukan evaluasi. Apabila dirasa ada materi yang kurang, dosen dapat meminta mahasiswa untuk melengkapinya agar seluruh materi dapat tercakup dalam video pembelajaran.

3. Kualitas video

Pada beberapa bagian dalam video, suara tidak dapat terdengar jelas. Hal ini sangat disayangkan, terutama jika bagian yang tidak terdengar adalah bagian penjelasan materi. Sebaiknya jika memang tidak memiliki peralatan yang memadai, pengambilan gambar dilakukan di tempat yang memiliki tingkat kebisingan kecil agar suara tetap dapat terdengar jelas.

\section{2 Pembahasan}

Penelitian ini dilakukan untuk melihat bagaimana edukasi perpajakan dengan video yang sesuai dengan generasi milenial. Seperti diketahui mahasiswa dengan rentang usia 18 sampai 20 tahun masuk dalam kategori generasi milenial sehingga dapat dijadikan sampel bagi penelitian ini.

Untuk mengetahui hasilnya, disebarkan kuesioner yang ditujukan untuk mahasiswa pembuat video dan mahasiswa pemakai video. Tabel dibawah ini menunjukkan apakah video pembelajaran Keuangan Publik membantu mahasiswa dalam memahami materi.

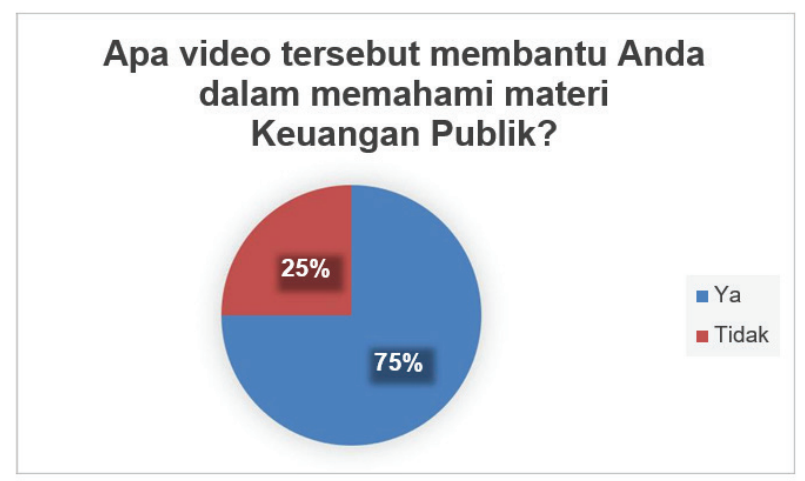




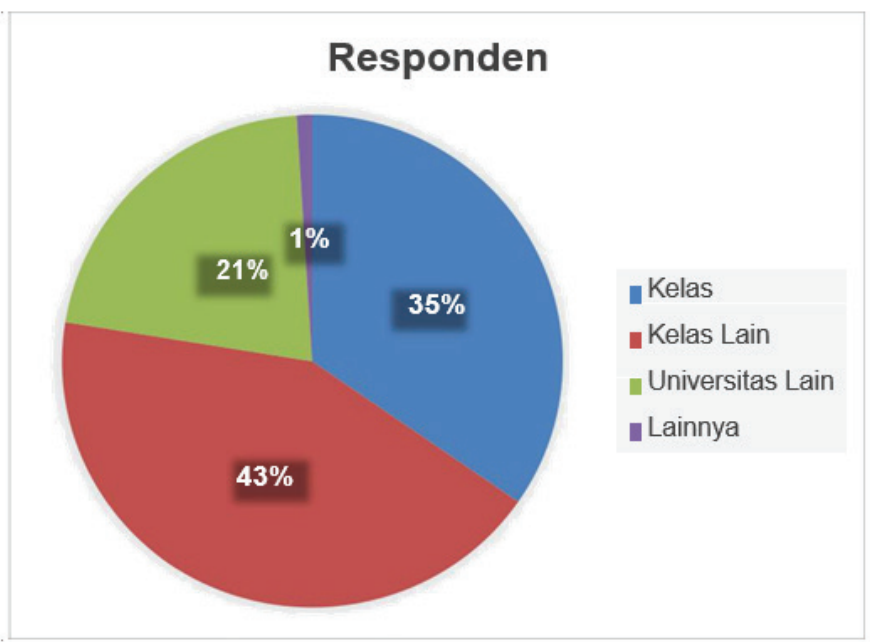

Jika dilihat secara keseluruhan, maka sebagian besar target penonton video adalah mahasiswa PKN STAN yang berasal dari kelas yang lain yaitu sebesar 43 persen. Selanjutnya mahasiswa kelas sebesar 35 persen, mahasiswa dari universitas lain sebesar 21 persen, dan hanya 1 persen untuk lainnya.

Selanjutnya, jika dibagi berdasarkan jumlah penonton maka hasilnya dapat dilihat pada diagram dibawah ini.

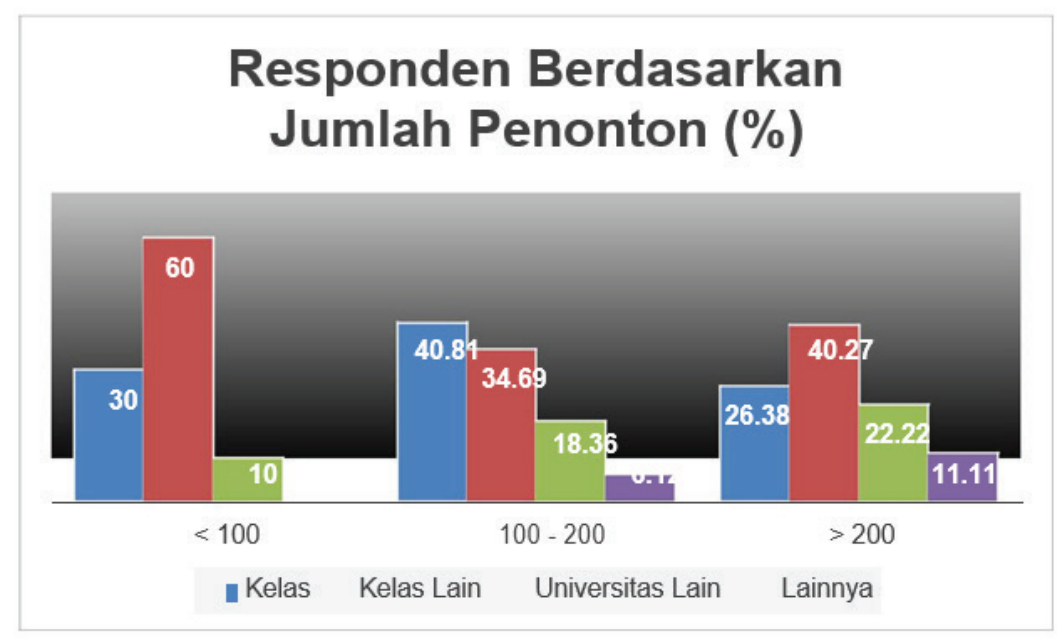

Dari hasil jawaban kuesioner, mahasiswa yang membuat video dengan jumlah penonton kurang dari seratus melakukan promosi video mereka paling banyak untuk mahasiswa PKN STAN yang berasal dari kelas lain yaitu sebanyak 60 persen. Selanjutnya diikuti dengan mahasiswa kelas sebanyak 30 persen, dan mahasiswa yang berasal dari universitas lain sebanyak 10 persen. Sementara mahasiswa pada kelompok ini tidak melakukan promosi kepada pihak selain itu.

Untuk video dengan jumlah penonton antara 100 sampai dengan 200, hasilnya menunjukkan bahwa promosi video paling banyak dilakukan kepada mahasiswa kelas 
sebanyak 40.81 persen, mahasiswa kelas lain sebanyak 34.69 persen, mahasiswa universitas lain sebanyak 18.36 persen, dan lainnya sebanyak 6.12 persen.

Selanjutnya untuk video dengan jumlah penonton diatas 200, hasil menunjukkan bahwa promosi paling banyak dilakukan untuk mahasiswa kelas lain sebanyak 40.27 persen, mahasiswa kelas sebanyak 26.38 persen, mahasiswa universitas lain sebanyak 22.22 persen, dan lainnya sebanyak 11.11 persen.

Dari hasil diatas, hal menarik yang dapat dilihat adalah peran dari promosi bagi mahasiswa universitas lain dan lainnya berbanding lurus dengan jumlah penonton video. Semakin tinggi proporsi promosi yang ditujukan untuk mahasiswa kelas lain dan lainnya, semakin tinggi pula jumlah penonton. Untuk kelompok pertama, jumlah penonton dibawah 100, proporsinya hanya 10 persen. Untuk kelompok kedua, jumlah penonton 100 sampai dengan 200, proporsi promosi yang ditujukan bagi universitas lain dan lainnya sebesar 24.48 persen. Selanjutnya untuk kelompok ketiga dengan jumlah penonton diatas 200, proporsinya paling tinggi yaitu sampai 33.33 persen. Hal ini dapat terjadi karena untuk promosi yang ditujukan bagi mahasiswa kelas dan kelas lain di lingkungan PKN STAN, jumlahnya cenderung tetap. Sehingga apabila ingin melakukan promosi video yang dibuat sebaiknya disebarluaskan ke pihak lain diluar mahasiswa PKN STAN karena jumlahnya tidak terbatas.

Selanjutnya untuk melihat metode yang digunakan oleh mahasiswa dalam melakukan promosi video mereka dapat dilihat dari diagram dibawah ini.

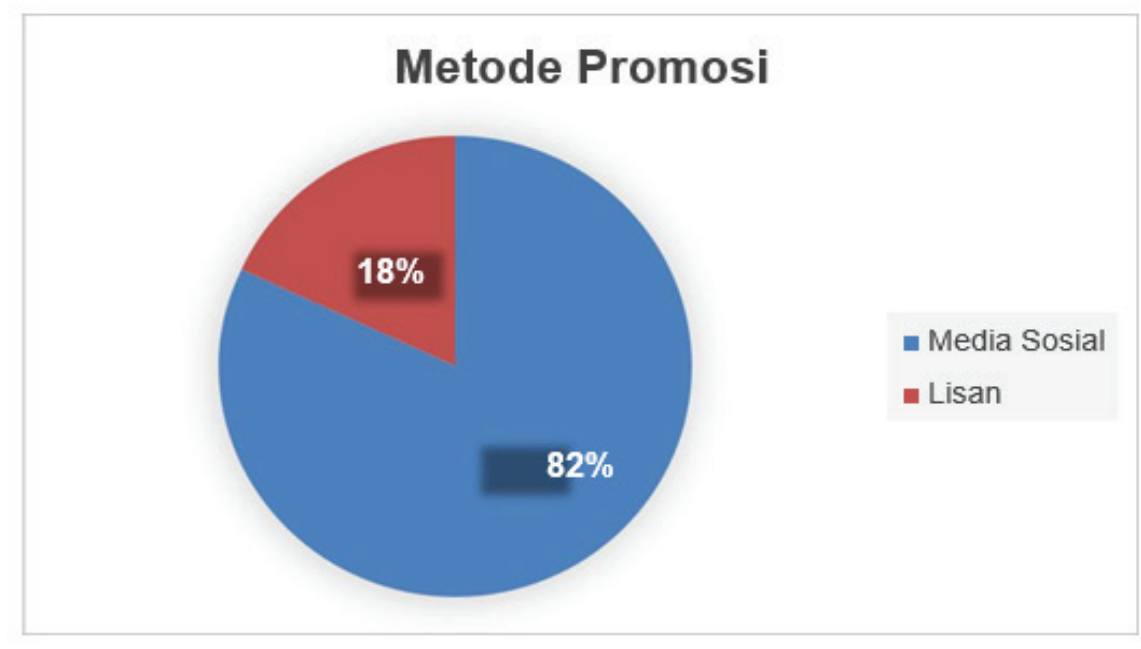

Dari kuesioner yang disebarkan kepada mahasiswa pembuat video, hasilnya menunjukkan hanya dua metode yang digunakan yaitu melalui media sosial dan lisan. Promosi melalui media sosial paling dominan yaitu sebanyak 82 persen, sedangkan promosi melalui lisan hanya 18 persen. Sesuai dengan karakter generasi milenial yang saat ini menggunakan media sosial untuk berinteraksi, promosi menggunakan media sosial dinilai lebih efektif karena praktis (dapat dilakukan dimanapun dan kapanpun) dan dapat menjangkau target sebanyak-banyaknya. 


\section{Metode Promosi Berdasarkan Jumlah Penonton (\%)}

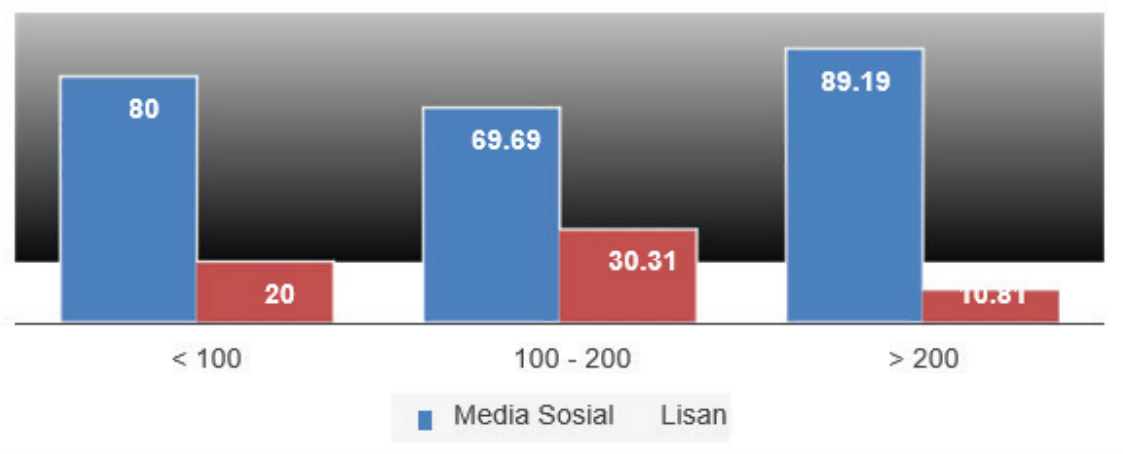

Jika dibagi berdasarkan jumlah penonton, dapat dilihat pada diagram diatas, pada seluruh kelompok terlihat bahwa metode promosi dengan menggunakan media sosial dominan jika dibandingkan dengan metode lisan dengan proporsi diatas 50 persen. Namun tidak terlihat adanya korelasi antara metode promosi tertentu dengan banyaknya jumlah penonton.

\section{SIMPULAN DAN SARAN}

\section{5a. Simpulan}

Dari hasil penelitian yang telah dilakukan, edukasi perpajakan dengan video yang sesuai dengan generasi milenial adalah sebagai berikut:

1. Menggunakan media sosial sebagai sarana penyebarluasan video. Hal ini sejalan dengan karakter generasi milenial yang telah menjadikan internet sebagai kebutuhan hidup.

2. Menggunakan konsep yang kreatif dan disesuaikan dengan selera target penonton.

3. Penggunaan video pembelajaran sebagai salah satu cara memudahkan mahasiswa dalam belajar terbukti membantu mahasiswa dalam memahami materi kuliah.

\section{5b. Saran}

Melihat efektivitas video pembelajaran sebagai salah satu metode yang memudahkan mahasiswa dalam belajar, maka direkomendasikan agar produksi video pembelajaran dapat diperbanyak dengan berdasarkan pada kurikulum mata kuliah di kampus. Terkait dengan edukasi perpajakan, metode video ini dapat digunakan sebagai salah satu metode penyuluhan untuk meningkatkan kesadaran perpajakan bagi generasi milenial. Untuk mendapatkan kualitas video yang baik, DJP dapat bekerja sama dengan dengan tax center untuk mengadakan lomba membuat video pembelajaran. 


\section{IMPLIKASI DAN KETERBATASAN}

Selain kesimpulan dan saran yang telah dikemukakan sebelumnya, peneliti juga menyadari bahwa juga terdapat beberapa keterbatasan dalam penelitian ini. Pertama, jangka waktu yang relatif singkat dalam mengerjakan penelitian ini mengakibatkan banyak hal-hal yang kurang maksimal, misalnya kualitas video pembelajaran. Kedua, jumlah sampel yang terbatas. Penelitian ini hanya menggunakan enam video pembelajaran. Jumlah yang relatif kecil untuk sebuah penelitian. Selain itu, pada penelitian ini mahasiswa pembuat video hanya berasal dari dua kelas D3 Pajak PKN STAN. Hal ini dikhawatirkan tidak cukup merepresentasikan kondisi sesungguhnya.

Mengingat pentingnya penelitian ini bagi DJP dalam rangka meningkatkan kesadaran perpajakan khususnya bagi generasi milenial sebagai calon Wajib Pajak, maka peneliti merekomendasikan penelitian ini untuk dikembangkan lebih lanjut, dengan beberapa saran sebgai berikut: 1) Jangka waktu yang lebih panjang dalam melakukan penelitian; dan 2) Memperbanyak jumlah dan variasi sampel yang digunakan karena latar belakang generasi milenial tidak hanya berasal dari mahasiswa.

\section{DAFTAR PUSTAKA}

[1] Afandi, Thohir. 2017. bappenas. 22 Mei. Diakses Desember 16, 2018. https://www.bappenas.go.id/index.php/download_file/view/26355/8804/+\& $\mathrm{cd}=8 \& \mathrm{hl}=\mathrm{en} \& \mathrm{ct}=\mathrm{clnk} \& \mathrm{gl}=\mathrm{id}$.

[2] Antalina, Ni Putu Dian. 2018. Salampajak. 31 Januari. Diakses Desember 16, 2018. https://salampajak.com/2018/01/31/generasi-milenial-generasi-z-dan-generasisadar-pajak/.

[3] Bencsik Andrea, Horváth-Csikós Gabriella, Juhász Tímea. 2016. "Y and Z Generations at Workplaces." Journal of Competitiveness 8 (3): 90-106. DOI: 10.7441/joc.2016.03.06.

[4] Cresswelll, John. 2015. Riset Pendidikan, Perencanaan, Pelaksanaan, dan Evaluasi, Riset Kualitatif \& Kuantitatif. Yogyakarta: Pustaka Pelajar.

[5] DJP. 2018. 20 Karya Terbaik Lomba Menulis Artikel Pajak Untuk Mahasiswa 2018. Jakarta: DJP.

[6] DJP. 2018. Transparansi Membangun Negeri: Keterbukaan Informasi Keuanganuntuk Kepentingan Perpajakan. Laporan Tahunan 2017, Jakarta: DJP.

[7] E Susantini, N Qomariyah. 2013. "Implementasi Metode Penugasan Analisis Video Pada Materi Perkembangan Kognitif, Sosial, Dan Moral." Jurnal Pendidikan IPA Indonesia 2 (2): 142-148.

[8] Embu, Wilfridus Setu. 2018. liputan6. 12 Mei. Diakses Desember 16, 2018. https://www. liputan6.com/bisnis/read/3523006/ pesan-sri-mulyani-kepada-generasimilenial-soal-bayar-pajak.

[9] Fanny Novita Yuwono, Deny Tri Ardianto, Erandaru. 2015. "Perancangan Video Pembelajaran Mata Kuliah Audio Visual Di Program Studi Desain Komunikasi Visual Universitas Kristen Petra." Jurnal DKV Adiwarna 1 (6): 1-12.

[10] Gani, Abd. Rahman A. 2014. Metodologi Penelitian Tindakan Sekolah. Jakarta: Rajawali Pers. 
[11] Ida Bagus Ari Arjaya, Ni Wayan Ekayanti. 2016. "Model Pembelajaran Inkuiri Dengan Media Video Berpartisipatif Terhadap Hasil Belajar Mahasiswa Unmas Denpasar Ditinjau Dari Motivasi Berprestasi." Jurnal Santiaji Pendidikan 6 (1): 57-67.

[12] Kusma, Adi. 2013. "Z Generation, World's Future Citizen." inspire, Juli: 10-11.

[13] Mardiati N, Restapaty R. 2018. "Pengaruh Penggunaan Media Video Pembelajaran terhadap Pemahaman Konseling Obat." Borneo Journal of Pharmacy 1 (1): 37-40.

[14] Mertler, A. 2011. Action Research Mengembangkan Sekolah Memberdayakan Guru. Yogyakarta: Pustaka Pelajar.

[15] Moleong, Lexy J. 2015. Metodologi Penelitian Kualitatif. Bandung: Remaja Rosdakarya.

[16] Muhammad Thamrin, Surnaherman, Sri Mona Riza. 2015. "Peningkatan Hasil Belajar Mahasiswa Kelas Agribisnis 4 Fakultas Pertanian Umsu Mata Kuliah Penyuluhan Pertanian melalui Media Pembelajaran Video." Jurnal Pendidikan IImu-IImu Sosial 7 (2): 166-175.

[17] Munir. 2012. Pembelajaran Jarak Jauh Berbasis Teknologi Informasi dan Komunikasi. Bandung: Alfabeta.

[18] Nasir, Mohammad. 1988. Metode Penelitian. Jakarta: Ghalia Indonesia.

[19] Nilasari. 2018. "Gerakan Sajak (Sadar Pajak): Upaya Peningkatan Kesadaran Pajak Bagi Generasi Milenial Guna Mewujudkan Pembangunan Berkesinambungan." Dalam 20 Karya Terbaik Lomba Menulis Artikel Pajak Untuk Mahasiswa, oleh DJP, 14. Jakarta: DJP.

[20] Nuraliyah, Dedeh. 2018. ddtc. 23 Januari. Diakses Desember 16, 2018. https://news.ddtc.co.id/mengubahpola-pikir-generasi-milenial-soalpajak-11841+\&cd=21\&hl=en\&ct=clnk\&gl=id.

[21] Pera Nurfathiyah, Armen Mara, Ratnawaty Siata, Aulia Farida dan Aprollita. 2011. "Pemanfaatan Video Sebagai Media Penyebaran Inovasi Pertanian." Jurnal Pengabdian pada Masyarakat (52): 30-36.
[22] RI. 2018. "Kemenkeu." Kemenkeu Web Site. 14 Desember. Diakses Desember 15, 2018. ht tps: / / w w w. kemenkeu.go.id/

[23] media/11142/uu-apbn-2019.pdf.

—. 2018. "Kemenkeu." Kemenkeu Web Site. 14 Desember. Diakses Desember 15, 2018. https://www.kemenkeu.go.id/ [24] media/11212/nota-keuanganbeserta-apbn-ta-2019.pdf.

Ron Zemke, Claire Raines, Bob Filipczak. 2013. Generations at Work Managing the Clash of Boomers, Gen Xers, and Gen Yers in the

[25] Workplace. New York: Amacom.

Silitonga, Samuel T M. 2018. "Menyambut Era Bonus Demografi demi Kemajuan Indonesia." Dalam 20 Karya Terbaik Lomba Menulis

[26] Artikel Pajak Untuk Mahasiswa 2018, oleh DJP, 47. Jakarta: DJP.

Sugiyono. 2015. Metode Penelitian Pendidikan. Bandung: Alfabeta.

Susanto, Hari. 2018. cnnindonesia. 15 Januari.

[27] Diakses Desember 16, 2018.

https://student.cnnindonesia.com/

[28] edukasi/20180115150552-445-268999 /cara-mengajak-generasi-milenial-untuktaat-pajak/.

Warsita, Bambang. 2011. Pendidikan Jarak Jauh, Perancangan, Pengembangan, Implementasi, dan Evaluasi Diklat. Bandung:

[29] Remaja Rosdakarya.

Winasti, Agnes. 2016. cnnindonesia. 23 Agustus. Diakses Desember 16, 2018. https://student.cnnindonesia.com/

[30] edukasi/20160823145217-445-153268/ generasi-millenial-dan-karakteristiknya. 